\title{
A new hybrid algorithm for global minimization of best proximity points in Hilbert spaces
}

\section{RAWEEROTE SUPARATULATORN ${ }^{1}$ and SUTHEP SUANTAI ${ }^{2}$}

\begin{abstract}
.
The purpose of this paper is to introduce a new hybrid algorithm for finding a global minimization of best proximity points for a new class of mappings, called best proximally nonexpansive (BPNE), which is weaker than nonself nonexpansive mappings and then prove strong convergence of the proposed method under some suitable conditions in real Hilbert spaces. Finally, some numerical experiment is also given for demonstrating our main result.
\end{abstract}

Acknowledgment. The authors would like to thank Chiang Mai University for the financial support.

\section{REFERENCES}

[1] Agarwal, R. P., O'Regan, D. and Sahu, D. R., Fixed Point Theory for Lipschitzian-Type Mappings with Applications, Springer, New York, 2009

[2] Basha, S. S. and Veeramani, P., Best proximity pair theorems for multifunctions with open fibres, J. Approx. Theory, 103 (2000), 119-129

[3] Basha, S. S., Best Proximity Points: Optimal Solutions, J. Optim. Theory Appl., 151 (2011), 210-216

[4] Basha, S. S., Best proximity points: global optimal approximate solutions, J. Global Optim., 49 (2011), 15-21

[5] Basha, S. S., Shahzad, N. and Jeyaraj, R., Best proximity points: approximation and optimization, Optim. Lett., 7 (2013), 145-155

[6] Berinde, V., Khan, A. R. and Păcurar, M., Coupled solutions for a bivariate weakly nonexpansive operator by iterations, Fixed Point Theory Appl., 2014, 2014:149, 12 pp.

[7] Berinde, V. and Kovács, G., Stabilizing discrete dynamical systems by monotone Krasnoselskij type iterative schemes, Creat. Math. Inform., 17 (2008), No. 3, 298-307 (2009)

[8] Berinde, V. and Kovács, G., Controlling autonomous scalar discrete dynamical systems generated by non self Lipschitzian functions, Creat. Math. Inform., 23 (2014), No. 2, 153-164

[9] Di Bari, C., Suzuki, T. and Vetro, C., Best proximity points for cyclic Meir-Keeler contractions, Nonlinear Anal., 69 (2008), 3790-3794

[10] Gabeleh, M. and Shahzad, N., Best proximity points, cyclic Kannan maps and geodesic metric spaces, J. Fixed Point Theory Appl., 18 (2016), 167-188

[11] Gabeleh, M., Best proximity point theorems via proximal non-self mappings, J. Optim. Theory Appl., 164 (2015), 565-576

[12] Goebel, K. and Kirk, W. A., Topics in Metric Fixed Point Theory, Cambridge University Press, Cambridge, 1990

[13] Haddadi, M. R., Best proximity point iteration for nonexpansive mapping in Banach spaces, J. Nonlinear Sci. Appl., 7 (2014), 126-130

[14] Jacob, G. K., Postolache, M., Marudai, M. and Raja, V., Norm convergence iterations for best proximity points of non-self non-expansive mappings, Politehn. Univ. Bucharest Sci. Bull. Ser. A Appl. Math. Phys., 79 (2017), $49-56$

Received: 04.07.2018; In revised form: 03.12.2018; Accepted: 10.12.2018

2010 Mathematics Subject Classification. 41A29, 90C26, 47H09.

Key words and phrases. Hybrid algorithm, Global minimization problem, Best proximity point problem.

Corresponding author: Suthep Suantai; suthep.s@cmu.ac.th 
[15] Kim, W. K. and Lee, K. H., Existence of best proximity pairs and equilibrium pairs, J. Math. Anal. Appl., 316 (2006), 433-446

[16] Kirk, W. A., Reich, S. and Veeramani, P., Proximinal retracts and best proximity pair theorems, Numer. Funct. Anal. Optim., 24 (2003), 851-862

[17] Martinez-Yanes, C. and $\mathrm{Xu}, \mathrm{H}$. K., Strong convergence of the CQ method for fixed point iteration processes, Nonlinear Anal., 64 (2006), 2400-2411

[18] Mogbademu, A. A., Strong convergence results for nonlinear mappings in real Banach spaces, Creat. Math. Inform., 25 (2016), No. 1, 85-92

[19] Nakajo, K. and Takahashi, W., Strong convergence theorems for nonexpansive mappings and nonexpansive semigroups, J. Math. Anal. Appl., 279 (2003), 372-379

[20] Pirbavafa, S. and Vaezpour, S. M., Equilibria of free abstract economies via best proximity point theorems, Bol. Soc. Mat. Mex., (2017), 1-11

[21] Raj, V.S., A best proximity point theorem for weakly contractive non-self-mappings, Nonlinear Anal., 74 (2011), 4804-4808

[22] Raj, V. S., Best proximity point theorems for non-self mappings, Fixed Point Theory, 14 (2013), 447-454

[23] Rathee, S. and Reetu, Common fixed point and best approximation results for subcompatible mappings in hyperbolic ordered metric spaces, Creat. Math. Inform., 24 (2015), No. 1, 77-82

[24] Srinivasan, P. S. and Veeramani, P., On existence of equilibrium pair for constrained generalized games, Fixed Point Theory Appl., 2004 (2004), 21-29

[25] Suzuki, T., Kikkawa, M. and Vetro, C., The existence of best proximity points in metric spaces with the property UC, Nonlinear Anal., 71 (2009), 2918-2926

[26] Suzuki, T., The existence of best proximity points with the weak P-property, Fixed Point Theory Appl., 2013, 2013:259, 6 pp

[27] Suantai, S., Cholamjiak, W. and Cholamjiak, P., Strong convergence theorems of a finite family of quasinonexpansive and Lipschitz multi-valued mappings, Afr. Mat., 26 (2015), 345-355

[28] Takahashi, W., Takeuchi, Y. and Kubota, R., Strong convergence theorems by hybrid methods for families of nonexpansive mappings in Hilbert spaces, J. Math. Anal. Appl., 341 (2008), 276-286

[29] Takahashi, W., Introduction to Nonlinear and Convex Analysis, Yokohama Publishers, Yokohama, 2009

[30] Zhang, J., Su, Y. and Cheng, Q., A note on "A best proximity point theorem for Geraghty-contractions", Fixed Point Theory Appl., 2013, 2013:99, 4 pp.

${ }^{1}$ DEPARTMENT OF MATHEMATICS

FACULTY OF SCIENCE

Ph. D. Program in Mathematics

Chiang Mai University, Chiang Mai 50200, Thailand

Email address: raweerote.s@gmail.com

${ }^{2}$ DEPARTMENT OF MATHEMATICS

FACULTY OF SCIENCE

Center of Excellence in Mathematics and Applied Mathematics

Chiang Mai University, Chiang Mai 50200, Thailand

Email address: suthep.s@cmu.ac.th 